\author{
Name: Lynne McCarthy \\ Affiliation: Queen Mary, University of London \\ Wordcount: 5,469 (includes bibliography and abstract) \\ Title: Aesthetics at the Impasse: the unresolved property of Dale Farm.
}

\begin{abstract}
'Soil Depositions' was an art activist project that responded to the 2011 Irish Traveller eviction at Dale Farm in Essex when three resident women donated small amounts of soil from the site of their former home. The soil was subsequently deposited, framed and documented in various national and international locations. This article discusses how the soil was dispersed and where this holds significance for the practice of nomadism in the UK, which through a series of legislation has been increasingly prohibited. The analysis attempts to bring clarity to the planning system discrepancies encountered by Dale Farm residents, and in doing so, generalises the common contemporary situation experienced by Travellers in the UK. These experiences are correlated to Lauren Berlant's idea of the 'impasse' (2011), which works as an affective descriptor of the post-eviction situation. The project aesthetically mediates the 'impasse' by reconfiguring the soil in primarily mundane and inconspicuous circumstances, and by symbolising the unresolved nature of Traveller claims to property. The aesthetic possibilities for re-working this razed soil were equally unresolved; it is cast within the project in both cultural and economic terms as material with little capacity for exchange. I draw on Appadurai's concept of the 'methodological fetish' to suggest that the soil's economic and cultural efficacy is dependent on a desire to give value to Traveller property.
\end{abstract}

\title{
Biography
}

Lynne McCarthy is studying for her Ph.D at Queen Mary, University of London. Her research examines performance, waste and the politics of property.

\section{Aesthetics at the Impasse: the unresolved property of Dale Farm.}

'Soil Depositions' is the title of an art activist project that re-appropriates property discarded in eviction. In particular, the project inspects the expulsion of 86 Irish Traveller families from Dale Farm in Essex on the $19^{\text {th }}$ of October 2011 as a way to consider how institutions of property within the UK, such as the planning system, enable participation. I argue that use-rights, or the way property is licensed, can preclude full participation in private, civic and political aspects of life. Claims made on property by nomadic groups, such as Irish Travellers are contentious, not least because the perception is that mobile lifestyles can be sustained without land tenure. While Travellers have not been historically disposed to land ownership, the privatization of halting sites in the UK has hegemonically imposed a regime of Traveller settlement in unauthorized developments since the early 2000s (Ryder 2011a, 31). The project, 'Soil Depositions', reuses the soil razed in the Dale Farm eviction as way to think about the dispossession and liquidation of property. Contributors to the project relocate the soil and distribute it in public spaces, showing how the circulation of this material in national and international contexts parallels the mobilities that are an assumed feature of nomadism. The reuse of soil from Dale Farm is a performative way to make visible how property-rights are a structural apparatus that, through restrictions and permissions, condition the agency of the user. The aesthetic purpose of the project is to imagine how use-rights can be extended into principles of participation. In what follows, I parse the principles of participation and aesthetics to the work of the project and to the material circumstances of Travellers.

From the $19^{\text {th }}-21^{\text {st }}$ of October, the residents and supporters of Dale Farm resisted forcible eviction until they were parted from their property by bailiffs and a reinforcement of over 100 hundred police. The expulsion of Dale Farm's three hundred residents engendered public interest in a polemic that on the one hand, appealed for the right to a private life through Article Eight of the Human Rights Convention, and on the other, petitioned for the breach of the planning system because the settlement at Dale Farm was an unauthorized development. In the final court hearing for Dale Farm residents, Mr. Justice Ouseley defended the planning system: 
...the harm to the Green Belt was weighed against the particular circumstances of the individuals, including their health, their education, their wish to maintain their way of life as travellers [sic], their aversion to bricks and mortar, the absence of other sites, in part at times the failure of the local authority to do all it should have done to assist. All those were considered but the conclusion has been reached time and again that this is the wrong site for travellers' accommodation (Ouseley 2011, section 145).

The spectacular nature and scale of the eviction at Dale Farm magnified how planning law can powerfully intercede in the right to a private life. Property seizure is intensely personal as seen by the agitation stirred between police, bailiffs, residents and activists at Dale Farm. I argue that this detachment from property mitigated the capacity for Travellers to reproduce their livelihoods.

Two months after the eviction I undertook a public action with three Traveller women, former Dale Farm residents, and the artists Kelly Green and Hannah Sharkey on the $18^{\text {th }}$ of December, 2011 to mark the United Nations International Migrant's Day (http://immigrantmovement.us/wordpress/lynne-mccarthy-kelly-green/ ). The women gave an audio account of their experiences of immobilization and impoverishment since the eviction, and we collectively uplifted small amounts of soil from the Dale Farm site. They gifted the soil as an occasion to make the aftermath of the eviction visible, and as a token of the diminished use-rights of their property. This aesthetic action staged questions of ownership and alienation as former residents were detached from their property for a second time.

The project, 'Soil Depositions' (http://soildepositions.wordpress.com 2012-) continued the action by prompting willing contributors to redistribute small parcels of the soil in spaces which to date include: the Department for Community and Local Government; the foundations of the forthcoming Olympic site in Brazil where mass land clearances have displaced many inhabitants of the favelas; the recently closed Traveller Resource Centre in Peckham; the Westway Traveller site on Latimer Road and Parliament Square, London. Contributors to 'Soil Depositions' were called through the Traveller Support Network and by word of mouth, and their participation focused on showing settled (Sedentarist) support for nomadism. By acknowledging the soil as the material remnants of eviction, 'Soil Depositions' countenanced the aesthetic regard held between people, their possessions and acts of dispossession that occur through forced evictions.

\section{Property and Travellers}

Traveller's legal access to property and their cultural attachment to property are politically unresolved, giving rise to complex misunderstandings between Sedentarist and nomadic property values. The 'institution of property', according to property theorist C.B. MacPherson, is an objective system of rights that endows the individual with the capacity to act freely with their possession (MacPherson 1962, 11). But, the institution of property also enforces how subjects can participate through its structures, for instance, the planning system. Nomadism troubles the statist and static nature of how property-rights are distributed since Traveller use of land is transient, and their relationship to jurisdiction is also less geographically fixed. The anthropologist, Christopher Griffin, connects Irish Travellers' seasonal patterns of movement with the practice of transhumance in their preference to travel in the summer and to retain a stable base in the winter $(2008,197)$. The modern static view of property was firstly conceptualized through John Locke's Two Treatise of Government ([1690] 1988) when the function of private property was to maintain exclusive use-rights for the owner as a guarantee of their personal freedom. These are absolute rights to dispose, use, or prosper from resources, and, in the liberal vein of possessive individualism, entail the right to exclude others from use or benefit. Travellers share resources and maintain socio-economic principles that are based on kinship (Griffin 2008, 199), which contentiously distinguish their use of property from Sedentarists. Mainstream attitudes to Travellers, Gypsy and Roma attest to the fact that cultural preconceptions are attached to property possession. 
The popular opinion that Travellers have an ambiguous disposition to property was exemplified by Leo McKinistry's comments in The Daily Express: 'if they are Travellers, then they should travel' (McKinistry 2011) - one of the many communiqués endorsing the Dale Farm eviction. Similarly, The Spectator has been petitioned for an apology by the Traveller Movement concerning an article entitled, 'What do we call travellers who are no longer traveling?' in which the term 'pikey' appears in the content (Liddle, 2013). The implication of the article is that the term Traveller bears no relevance to people who have settled, and in the author's view, renders the Traveller identity redundant. Moreover, the dispute at Dale Farm vexed Sedentarist expectations of how Travellers should behave because residents resisted eviction, raising questions about present consensus on the function of property.

Infringements on nomadism and encampments began in the UK through The Caravan Sites (Control of Development) Act 1960 , which closed existing halting sites. This act was superseded by 1968 Caravan Sites Act, which introduced the statutory provision of public Traveller sites. Between 1968-1994 this ensured the successful delivery of 350 sites (Community Law Partnership, 2010). The duty to provide public sites was abolished in the 1994 Criminal Justice and Public Order Act and the successive Circular 01/1994 enforced the privatization of sites by encouraging Travellers to buy their own land for settlements (Ryder, 2011b). Not least, the 1994 Act criminalized roadside halting, and to avoid the prospect of continuous eviction, many Travellers opted to buy land in the hope of gaining retrospective planning permission (Ryder 2011a, 36-37). More recently, planning policy under the Regional Spatial Strategies and Circular $01 / 06$ have required that local authorities assess the need to provide authorized sites through the Gypsy and Traveller Accommodation Assessment, but without the need to fulfill that provision (Ryder 2011a, 32 and Richardson 2013, 21-42). It is worth noting that Basildon District Council had identified the need for an extra sixty-two pitches at the time the Dale Farm Travellers were cleared. By 1997 as many as $90 \%$ of Traveller applications for private purchase of land were refused by local planning authorities (Cemlyn, Greenfields, 2009, 8), which suggests there is an indirect discrimination towards Travellers within the planning system.

Contestations about Traveller property are more frequently played out in the UK at the municipal borders of Local Authorities and Local Planning Authorities, but the planning dispute at Dale Farm became a national discussion (due to the campaigns of the Dale Farm Residents Association, The Traveller Support Network and The Irish Traveller Movement in Britain), and indexed a broader Irish and European discrimination against Roma, Gypsy and Travellers (Wickstrom 2011; Power 2004; McVeigh 2007). While Traveller claims to property are delegitimized in public debates, the lesser known fact is that Irish Travellers, Gypsy and Roma routinely encounter enforced evictions in the UK, and this has had an impact on the basic right to shelter (Irish Traveller Movement in Britain 2011; Ryder and Acton 2011; Ryder and Greenfields 2010; Roughneen 2010; Richardson 2012). The advocate for Travellers rights, Gratton Puxon, has claimed that similar to any other ethnic group, Traveller culture evolves and is currently undergoing a shift in respect to property, health and education that is slowly aligning with Sedentarist views (Puxon, 2011). 


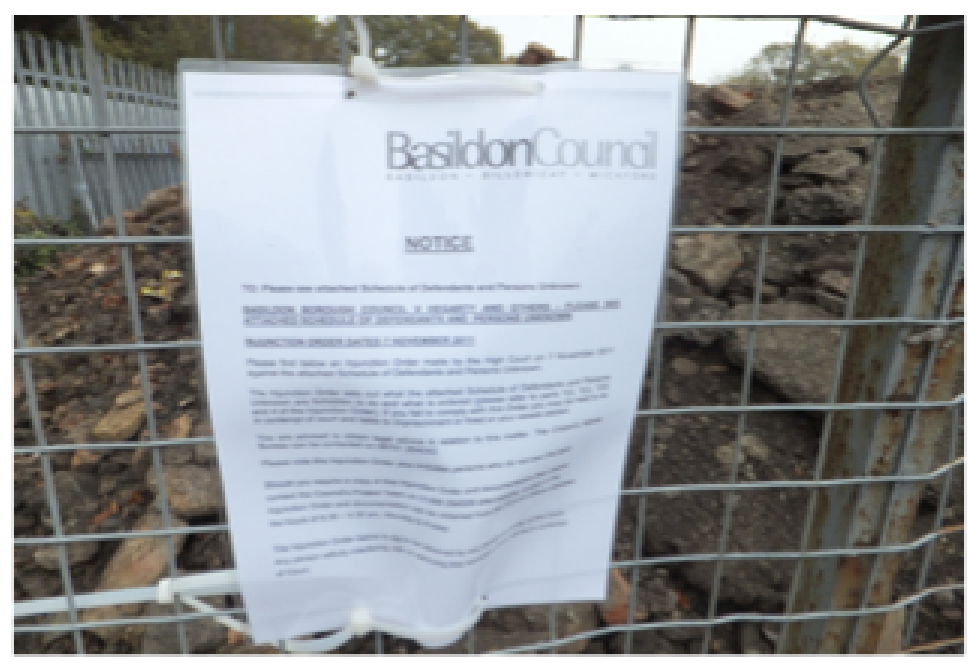

Figure 1 Dale Farm, November 2011, Eviction Notice. Image: Lynne McCarthy

\section{Aesthetics at the Impasse}

Lauren Berlant frames aesthetics as the 'metrics for understanding how we pace and space our encounters with things' (Berlant, 2012, 12), and I elaborate on this definition by considering the aesthetic affects of being detached from possession. I draw on Berlant's work on 'crisis ordinary' and 'the impasse' to understand aesthetics as the condition of living in the contemporary moment when infrastructures for reproducing life collapse. Berlant describes attachments not just as material objects, but as 'clusters of promises' about how life can be reproduced (2012, 23-24). The cluster of promises given to Travellers were to construct and maintain their own settlements in return for the closure of public halting sites and to discontinue their seasonal movement (Ryder et al 2011b). Yet, even when Travellers attempt to comply with this, they are not supported by appropriate allocation of sites by Local Planning Authorities and also risk the accusation that they are not behaving nomadically by refusing to 'move on'. Not least, detachment from property carried out through enforced eviction defiles 'our encounter with things' (12), and I argue that participating within property structures as a mode of living is an aesthetic condition that when undone produces crisis.

The Irish Traveller residents who privately purchased the land in 2001 returned to the verges of Dale Farm after the initial eviction. Those residents who had returned, did so, because they had not been offered alternative ethnically appropriate accommodation elsewhere. Berlant's concept of the 'impasse' as a 'situation without a narrative', describes the current stasis of Travellers, who, due to the legislation described above, have diminished means to sustain nomadism or to reside in ethnically-appropriate accommodation $(2011,199)$. Berlant notes that there is a 'holding pattern' implied in 'impasse' $(2011,5)$, which for Travellers is the uncertainty and contradiction of being both immobilized, but unwanted in any specific location. I also use it here to outline the legal impasse faced by Travellers since their purchase of Dale Farm and the precipitation of a decadelong planning permission dispute. The Irish Traveller Movement in Britain took stock of residents who had on several occasions applied for the pertinent planning permission for Dale Farm (2011 http://irishtraveller.org.uk/wp-content/uploads/2011/09/12.09.11-21.pdf). After several failed attempts by residents to attain permission, Basildon District Council and the Department for 
Local and Community Government moved to expel them in 2005. The ruling to enforce eviction was repealed by the Travellers, but was taken forward again by Basildon Council and won at the Court of Appeals in 2009.

Berlant's 'crises ordinary' are the everyday situations in people's lives where assurances and certainty in labour, housing, and political governance have been worn down by the imperative to navigate relentless risk and personal responsibility (2011). Although, a Sedentary perspective might view eviction as exceptional, Travellers envisage it as a continuous prospect. The "crisis ordinary' unfolds when irregular but routine adjustments to, for instance, precarious labour or unstable shelter become the ordinary aspects of the everyday. The 'crisis ordinary' is an aesthetic disposition, one in which everyday affects attenuate the capacity to reproduce life. In their audio account for 'Soil Depositions', the three Traveller women at Dale Farm narrated the events of the eviction while surveying the remains of where their homes stood. The women articulated their irritations as the lack of daily amenity to get things done, such as no access to drinking water, toilets, showers, stable electricity and the expense of running generators to heat poorly insulated caravans.

Possession is another aspect of property that encompasses the subjective experience of ownership (Strathern 1999, 140), personalizing the way that people are disposed to use objects in the enclosed space of the home. For Travellers, possession may be reflected both in the subjective and collective experience of ownership, for instance Travellers are largely known to prefer the use of mobile trailers, which is also a distinguishing aspect of Traveller identity. Therefore, I consider the way in which belongings are used to be a performative construction of personhood, but when use is disrupted by the antagonism of eviction, then the politics of possession are exposed in terms of who has a right to possess certain resources where and how. Consequently, restricting userights may have deleterious affects on identity especially when usership is cultural in expression.

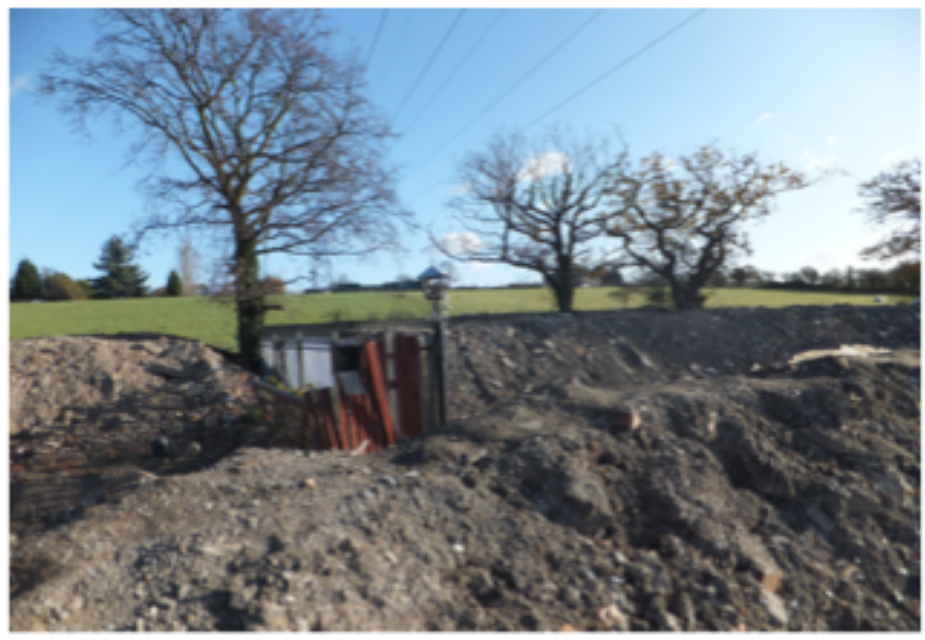

Figure 2 Dale Farm, November 2011. Image: Lynne McCarthy

Recurring enforcement notices made against Traveller settlements are also an understated acknowledgement of Traveller resilience in the capacity to reproduce life. Sinead Ní Shuinéar, a Traveller and academic writes this about Traveller kinship: 
The core values of Irish Travellers include: self-employment, occupational flexibility, priority of social obligations based on kinship over everything else, nomadism as a functional corollary of the above and as a value in itself, strict segregation of pure and impure, versatility, adaptability, and skill in the delicate art of living on and supplying the market demands of the non-Traveller majority, without losing their Traveller identity (Ní Shuinéar cited in McCann and Ó Síochain 1994, 55).

It appears that Travellers have always been making the kind of adjustments Berlant tells us are now prevailing as a crisis of the ordinary for the neoliberal subject. Phien O'Phien, a Traveller and Sean Nós (oral historian), has explained in an interview that the canon of Irish history claiming that Irish Travellers originated from the evictions in the Irish famine (1848) is misleading. O' Phien states that Irish Travellers thrived in the famine, having the adaptable economic means to carry on in spite of the diminishing resources of the land, and most notably, because of the skill of transhumance (19 October 2012, London). Traveller economies are transient, fulfilling roles and occupations that would not be profitable for larger businesses, because they are seasonal in nature or because the market is too small (Griffin 2008, 229-242). However, this resilience is diminishing through an increasingly technological and literacy-based labour market, which is difficult for many Travellers to navigate from within their oral cultures.

\section{Soil Depositions: Participation and Circulation}

'Soil Depositions' circulates the property of Dale Farm Travellers, and in doing so takes up on this situation of the impasse. The project and its contributors extend the use-rights of the Travellers' property in ways that the Traveller's themselves cannot. After the eviction Traveller owners were prevented from any usual form of use attributed to proprietorship either through labour or leisure as Basildon District Council, the initiators of the eviction, instructed bailiffs to mount banks of soil known as 'bunding'. These banks obstructed each plot and pre-empted a reoccupation of the land, which emphasized how Traveller property is treated. The fact that the Travellers cannot use the soil even for greenbelt purposes illustrates how use-rights are fundamental to structures of participation.

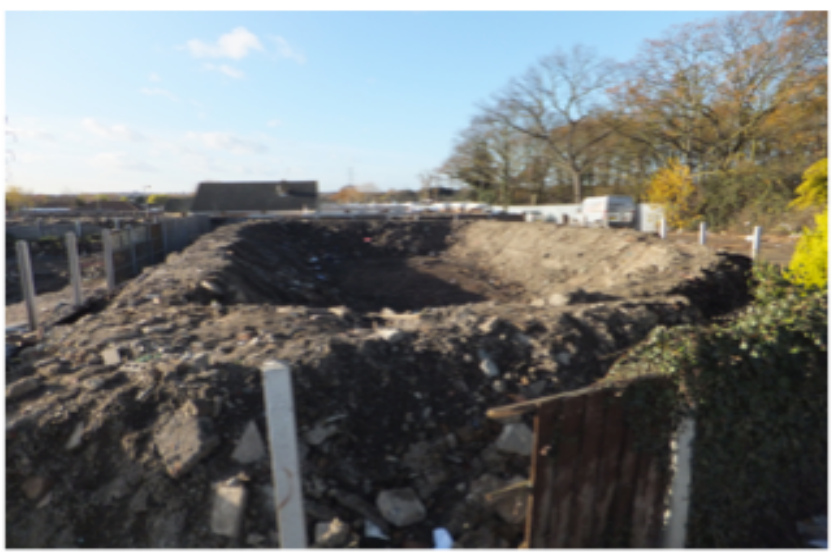

Figure 3 Dale Farm, February 2012, Bunding, Image: Lynne McCarthy 
'Soil Depositions' focuses on participation as the way property is exchanged between people. By circulating the Dale Farm soil, contributors parallel how Arjun Appdurai (1986) sees exchange as a social form. Any given economic exchange is a social transaction that is concealed by the mundanity of the 'small-scale exchange of things in ordinary life'(1986, 57). These social transactions are muted across the everyday, he states, and 'are based on a set of agreements concerning what is desirable, what a reasonable 'exchange of sacrifices' comprises, and who is permitted to exercise what kind of effective demand in what circumstances' (57). All social transactions are political and are underscored by 'relations of privilege and social control'(57). As a commodity of the Dale Farm Travellers, their soil was economically devalued through the inhospitality of eviction, and by laying their land to waste, the eviction restricted the prospect of future exchanges and social transactions. In 'Soil Depositions' the social transaction occurred in the moment the three women gifted the soil, and its circulation by other participants, was an attempt to show the effort and difficulty of reinstating sociability, albeit through aesthetic means.

Commodities are not just things with market values but things with 'social potential' (Appadurai, 1986, 6). Soil may not initially appear as a commodity since it more mundanely appears as dirt, but when thought of as a component of land, it is a primary commodity-form. Moreover, the eviction razed Travellers' land to waste-status, effectively de-commoditising it. Defined one way as 'the social control of value' (Thompson cited in Moser 2002, 92), waste that is made in one situation can offset an increased value elsewhere. For example, in the campaign to dispel Irish Travellers from Dale Farm, their nearest neighbour publically spoke about returning value to his property (Coutts, $\mathrm{http} / / \mathrm{www}$.youtube.com/watch? $\mathrm{v}=\mathrm{t} 2 \mathrm{tzBesiQno}$ ). Dale Farm soil is particular because of its devaluation in eviction. It may help to quantify this: it cost £8million to dismantle what had been originally purchased by the Travellers at $£ 1.5$ million, and furthermore, the injunction that the soil could no longer be used by the residents depreciated its standing value while accruing other costs to the Travellers forced into alternative means of living. Additionally, Basildon District Council has charged the residents with the cost of the eviction.

These valuations demonstrate disproportionate relationships between the original price of the land and the social worth of removing Travellers, a conversion that is economically calculated as $£ 8$ million. 'Regimes of value' are both economic and social, but it is striking that an equivalence can be struck for both regimes, for instance, the desire to pay for the removal of the Travellers illustrates 'relations of privilege' that are at variance with Travellers' expectations of value (Appadurai 1986,15, 57). In this instance, the transaction is anti-social and is not based on a desire to bring a commodity, or the subjects of a commodity-exchange closer, but to repel it by aesthetically putting it out of order.

Thinking through the circulation of the Dale Farm soil in 'Soil Depositions', I consider how value can be re-attributed to apparently worthless material. Contributors photographed the soil as it was trod upon, planted, dispersed or re-arranged; some images play on the unspectacular qualities of soil, others made its placement conspicuous. I read the aesthetics of 'Soil Depositions' as the ways parties are seen to use the soil or make claims on it. Some contributors inevitably repeated a disowning of the soil, signaling its disregard as an aesthetic equivalence to the disregard shown to the Travellers. Others have carefully transferred it to similar contexts of displacement such as the favelas in Rio, Palestine and more recently to a Native American reservation in Arizona. Significantly, ex-residents of Dale Farm who have relocated to Cambridge worked with the artist Beverley Carpenter (a supporter of Travellers over the duration of the eviction) in the arts project, 'Our Land Our Lives' (Cambridge, 2013). They used the soil to pot plants in a generative gesture that could be read as a future flourishing that reaches beyond the 'impasse'. Despite the fact that the project uses aesthetics to re-commoditise the soil by situating it within an aesthetic regime of value, it is not clear that the project's continued dispersal of the soil, or its capacity to act as a repository, will be either aesthetically satisfying or, indeed, have an aesthetic value that translates for the Travellers into other sustained values. Instead, the project attempts to reveal the unresolved nature of social transaction between Travellers and Sedentarists. 
$42-45$ B E.L S I Z E P A R K. 10 Magnificent Homes EACH A MASTERPIECE OF

ssical \& Contemporary Elegance

www.galliardhomes.com

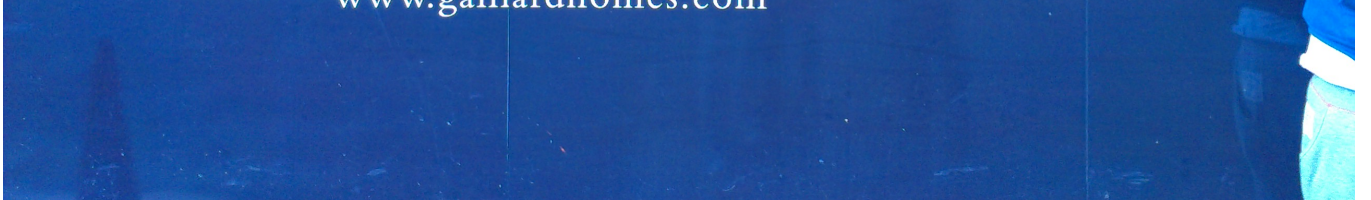

Figure 4 Belsize Park, London, March 2012. Image: Danielle James

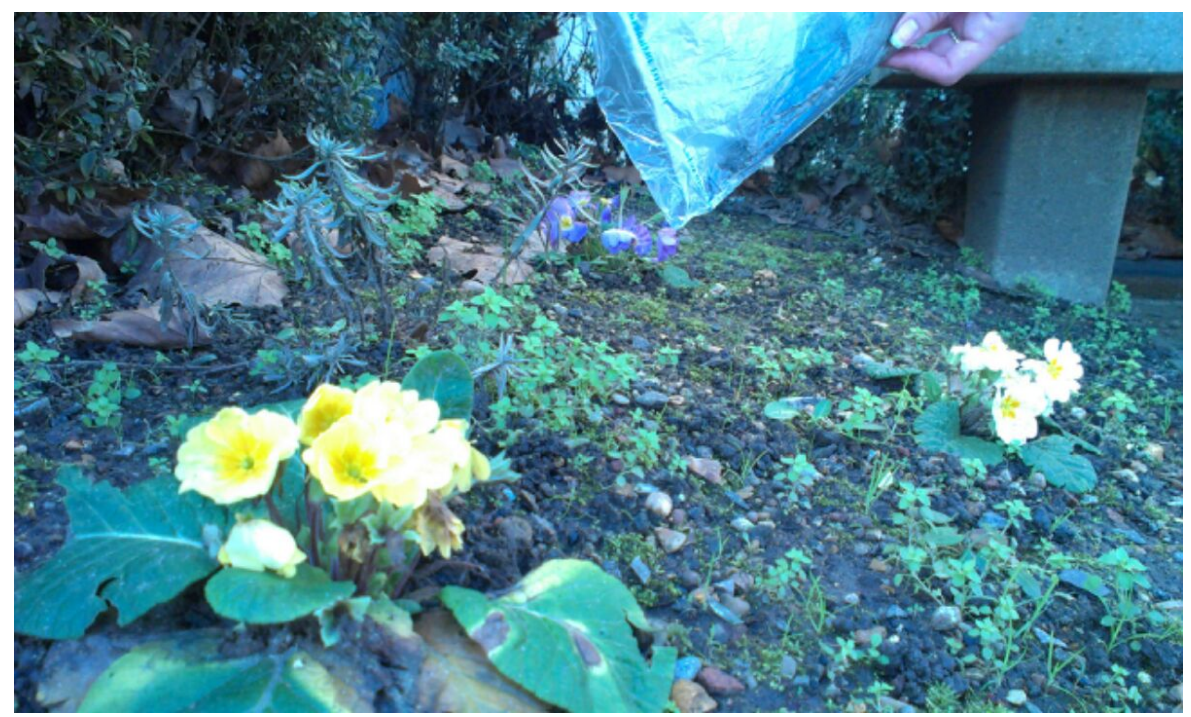

Figure 5 Primrose Hill, London, March 2012. Rebecca Fox 

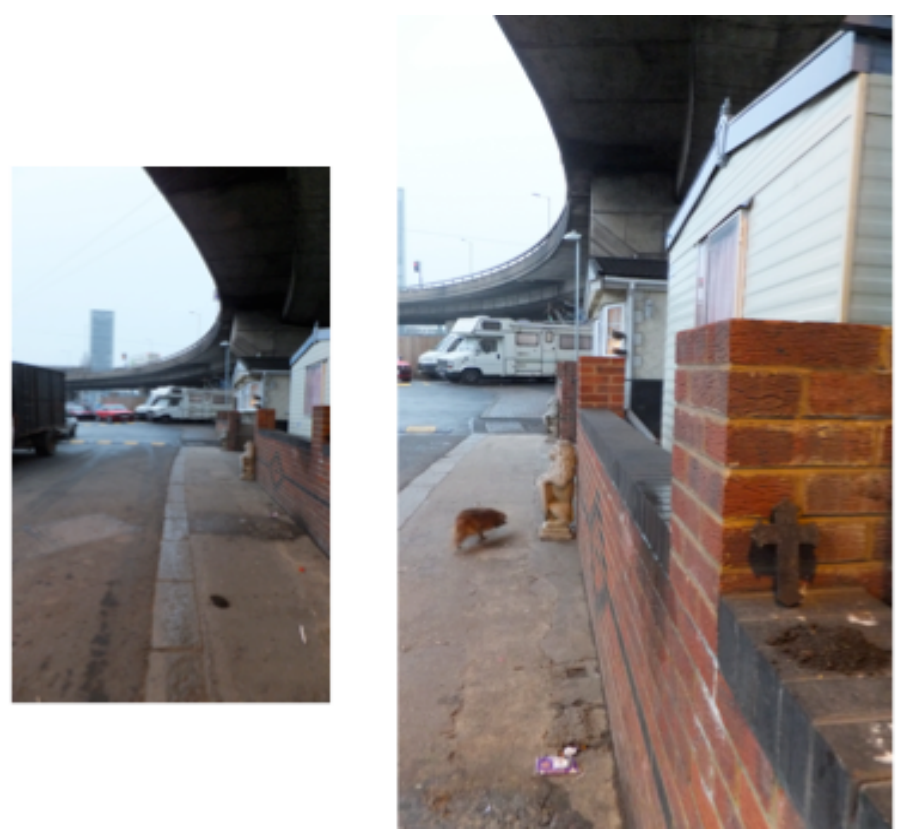

Figure 6 The Westways Travellers Site, London, June 2012. Image: Lynne McCarthy

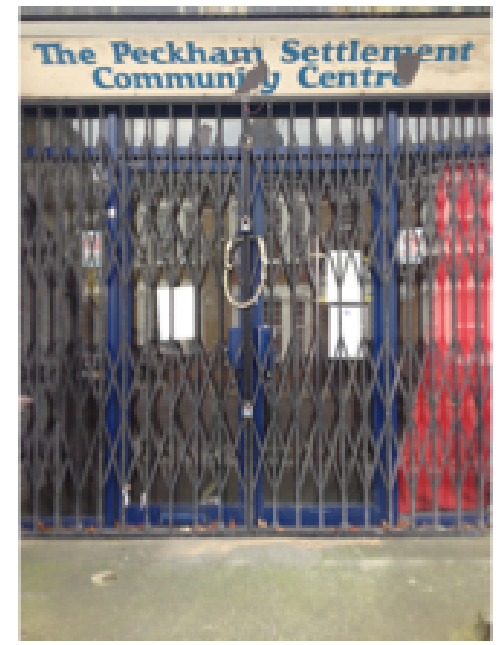

Figure 7 The Peckham Settlement Community Centre, London, July 2012. Image: Charlotte Bell. The soil is strewn at the entrance to mark the closure of the Traveller centre in Peckham. 


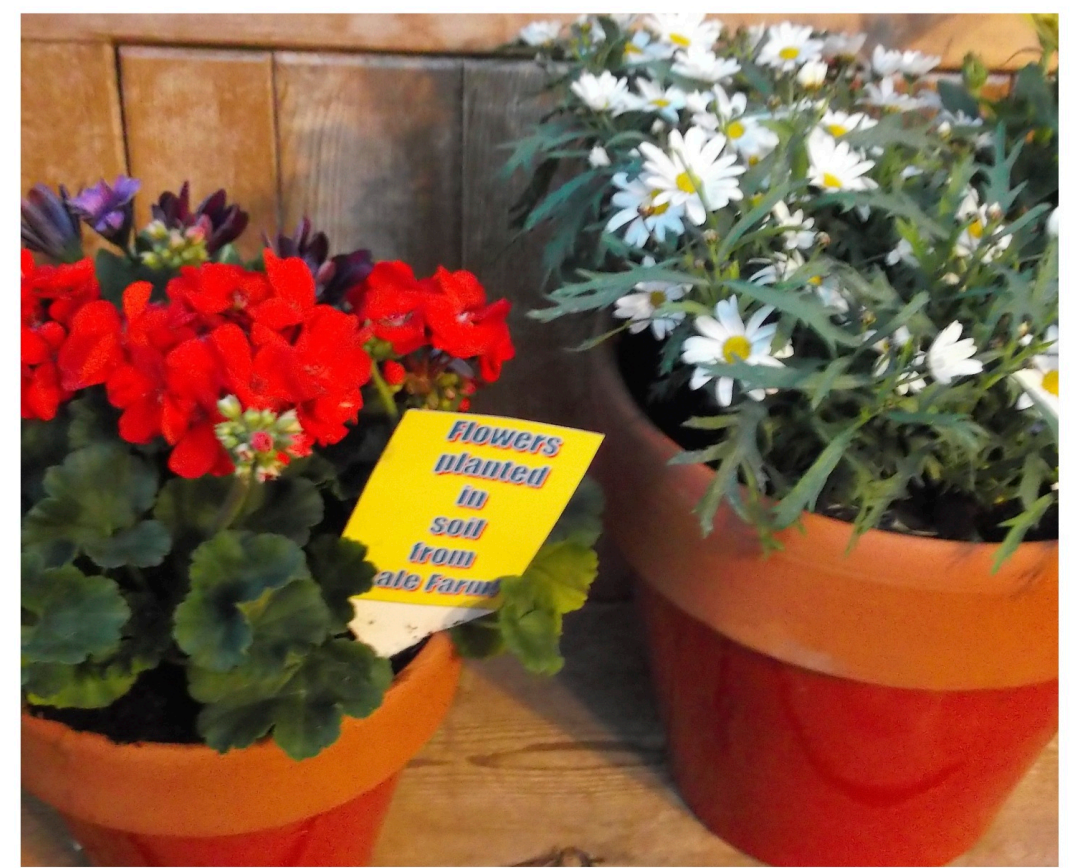

Figure 8 Our Land Our Lives, Cambridge, May 2013 Name: Beverley Carpenter and Tina McCarthy (former Dale Farm resident).

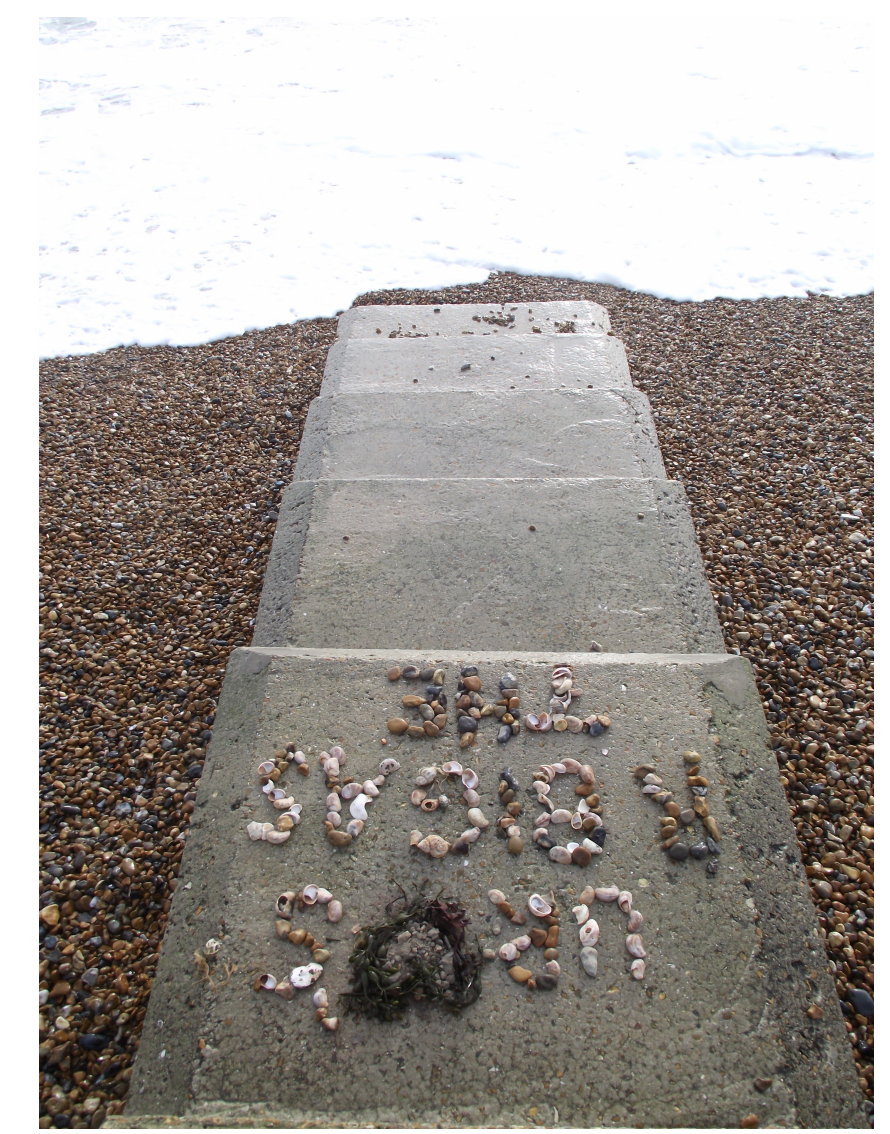

Figure 9 Your Hearts are as Big as the Sea, Brighton, January 2015: Name Helena Walsh and Ella Walsh

What is palpably absent from the aesthetic and political aspects of this work is a manifestation of sets of bodies working in proximity, as a fantasy of bringing things together. Instead, participation is dispersed and is only measured by contributors in the act of dislocating and 
photographing the soil. In this approach, performance and participation are not coupled in the same temporality and the project is reasoned on the idea that bodies need not be performatively co-present in order for an action to occur, or to have occurred, or to produce a social effect. Appadurai describes exchange as the desire to bring something closer and the paradox for contributors is their desire to bring Traveller property within proximity and to make it transactable through the aesthetics of the project. The circulating soil represents the isolation of nomadism, but it is also possession that has been alienated from its owners, and this sets a challenge in terms of what can be kept either in proximity or at a distance. Yet, contributor's participation is also diffuse and proceeds in multiple directions that don't require a unified location, and thereby the deposited soil becomes as much a marker of alienability as mobility.

The dispersal of the soil symbolically conveys the practice of nomadism. Paradoxically, the person who drops the soil is operating through a mobility and a freedom of movement that is assumed to be attributed to Travellers' lifestyles, but which has been largely curtailed across Europe. I am cognizant of the role of the artist, or any contributor, in their capacity to reproduce itinerancy particularly in this instance of site-based activist work. Dean Kenning writing on the artist-creator, whose name is often the cultural capital that is brought to participatory arts projects, remarks on how often artists can be physically absent from projects. Kenning extends Miwon Kwon's idea of the 'itinerant artist' 'city hopping from one art institution to another '(473):

All too often participation accrues to the artist and the social dimension becomes an aesthetic backdrop to a successful career....that initially suggests itself as a politics of art stemming from an understanding of the artist's own place in the production of relations in which he or she operates, leading to a transformation of those relations' (437).

When contributors to the project take possession of the soil, albeit gifted by the Travellers, a statement ensues about who can stake a claim in its use-rights, and the project palpably performs a second dispossession. Understood this way, I don't seek to exalt participation, but intend to show who has participatory privilege and to underline that participation enlivens the circulation of things. The action taken on things within social circuits is a reminder of Appadurai's 'methodological fetishism' where 'things-in-motion' reveal their 'human and social context' $(1986,5)$. 'Soil Depositions' is a practical method for understanding how things are circulated as detached possessions.

\section{The Legal Impasse}

'Soil Depositions' takes account of legal restrictions made against nomadism under consecutive UK legislation. Richard Sheridan, chairperson of Dale Farm Residents Associations, has stated at the Council of Europe that Dale Farm Travellers could neither legally travel, nor legally make use of land they purchased (Strasbourg, December 8, 2011). Within the boundaries of the project, the term deposition is deployed in all its definitions: as a legal term for the presentation of evidentiary material before a court; as an act of deposing a person from a position, and as material that is deposited. All three meanings are relevant to the eviction at Dale Farm in the following sense; where do people go after an eviction, where do people's possessions go, and who should account for this?

The 'Soil Depositions' project aesthetically mediated the impasse as a configuration of the current situation of Dale Farm Travellers by drawing attention to the ways the initial eviction detached residents from their possessions. The project reappraises the value of such dispossession in two ways. Firstly, it knowingly detaches the residents for a second time from their property. Contributors depositing the soil are second- member participants, described by Nancy Fraser as those outside an identity group who must in a 'deliberative democracy' assemble around a justice claim in order for it to be intelligible (Fraser 1993), as well as lending a participatory privilege that is not necessarily extended to Travellers within the state (498). Contributors with an 'outsider perspective' make this concern a 'common concern' (501), and as such, the project adheres to forms of activism that are a direct demand for change. 
Secondly, by creating an increased distance between the possessors of the material and its final deposition, the images produced by contributors configure the soil as a fetish. The absence of Dale Farm Travellers from the expanded project compounds their alienation and immobilization, particularly at a time when their primary needs were a more pressing concern. In terms of an aesthetic decision, it is precisely the absence of Travellers from many public spheres that is both critical and political. It is critical in the sense that Travellers are now residing in a state of exception, both beholden to, and outside of the states care. This alienation of person from possession in the final presentation of the work poses not only the question of the quality of social relations that are carried through objects, but also the quality of relations between Sedentarists (settled people living in static homes) and Travellers.

What can the project, 'Soil Depositions' do about the conjunction between identity, use-rights and property? I return to Berlant's term 'impasse' which is 'decompositional - in the unbound temporality of the stretch of time, it marks a delay that demands activity. The activity can produce impacts and events, but one does not know where they are leading' $(2011,199)$. The eviction constructed an impasse of homelessness for Travellers that has lasted for three years, while, the suspension of the ethnically-preferred use of their property impaired the agency of Travellers to conduct their lives as Travellers. Although, the Dale Farm soil was deemed to be in misuse by court order, it is ironic that the aesthetic re-use of the soil permits a variety of other functions not available for Travellers. The soil itself is symbolic of nomadism, and by putting it into circulation it magnifies the Travellers' lack of agency to form attachment to place on their own terms. It further compounds the dispossessed state of the Travellers by pointing to the devaluation of their identity through the circulation of their dismantled possession. Consequently, the soil itself demands the 'revision of an unsolved situation' (Berlant 2011, 199).

\section{Reference List}

Appadurai, Arjun. 1986. The Social Life of Things: Commodities in Cultural Perspective.

Cambridge [Cambridgeshire]; New York: Cambridge University Press.

Berlant, Lauren. 2011. Cruel Optimism. Durham; London: Duke University Press.

Community Law Partnership. 2011. Back to the Past: Planning for Traveller Sites. Traveller

Times. http://www.travellerstimes.org.uk/blog.aspx?n=9309758e-e68b-4245-9805-

fc57520c0db5\&c $=$ f1b1c82c-0f3c-4edf-98cd-502ea80ed8fa

Cemlyn, S., M. Greenfields, S. Burnett, Z. Matthews, and C. Whitwell. 2009. Inequalities

Experienced by Gypsy and Traveller Communities: A Review. Bristol.

http://www.equalityhumanrights.com/uploaded_files/research/12inequalities_experienced by_gyp sy and traveller communities a review.pdf.

Coutts, Daniel. 2011. The Battle of Dale Farm: Traveller Eviction Part 2. Youtube

http://www.youtube.com/watch?v=t2tzBesiQno

Fraser, Nancy. 1993. Rethinking the Public Sphere: A Contribution to the Critique of Actually

Existing Democracy. In The Cultural Studies Reader, ed. Simon During, 488-506. London; New

York: Routledge.

Great Britain. 1981. Representation of the People Act 1981.

http://www.legislation.gov.uk/ukpga/1981/34/contents.

Griffin, Christopher. 2008. Nomads under the Westway: Irish Travellers, Gypsies and Other

Traders in West London. Hatfield: University of Hertfordshire Press.

Irish Traveller Movement in Britain. (2011). Dale Farm: Basildon Council's Eviction of a

Traveller Community, March. http://irishtraveller.org.uk/wp-content/uploads/2011/09/12.09.11-

21.pdf

Kenning, Dean. 2009. Art Relations and the Presence of Absence. Third Text 23, no. 4: 435-446.

Liddle, Rod. 2014. What do you call Travellers when they are no longer travelling? The Spectator. October 26. http://www.spectator.co.uk/columnists/rod-liddle/9064071/what-do-we-call-thepeople-who-abducted-maria-its-a-minefield/ 
McKinistry, Leo. 2011. Dale Farm fiasco should have been resolved years ago. Daily Express, October 20. http://www.express.co.uk/comment/columnists/leo-mckinstry/278466/Dale-Farmfiasco-should-have-been-resolved-years-ago

MacPherson, C.B. 1962. The Political Theory of Possessive Individualism: Hobbes to Locke. London: Oxford University Press.

McVeigh, Robbie. 2007. Ethnicity Denial and Racism: The Case of the Irish Government of Ireland Against Irish Travellers. Translocations: The Irish Migration, Race and Social Transformation Review 2, no. 1: 90-133.

Mr. Justice Ouseley. 2011. The Queen on the Application of Mary Sheridan, Cornelius Sheridan and Others. Margaret McCarthy v Basildon District Council. High Court of Justice, Queen's Bench Division. http://www.bailii.org/ew/cases/EWHC/Admin/2011/2938.html.

Ní Shuinéar, Sínead. 1994. Irish Travellers, ethnicity and the origins question. In Irish Travellers: Culture and Ethnicity, ed. M. McCann, S. Ó Síocháin, and J. Ruane, 54-60. Antrim: Institute of Irish Studies Queen's University of Belfast.

Power, Colm. 2004. Room to Roam: England's Irish Travellers. Report of Research funded by The Community Fund. http://www.statewatch.org/news/2005/feb/Room-to-Roam-England'sIrish-Travellers.pdf

Puxon, Grattan. 2011. Interview by Lynne McCarthy, Video. December 18. Dale Farm, Basildon, Essex.

Richardson, Joanna. 2012. Gypsies and Travellers: Empowerment and Inclusion in British Society. Bristol UK: Policy Press.

Roughneen, Dualta. 2010. The Right to Roam: Travellers and Human Rights in the Modern Nation-State. Newcastle: Cambridge Scholars.

Ryder, Andrew. 2011a. Big Bang Localism and Gypsies and Travellers. Corvinus Journal of Sociology and Social Policy 2, no.2: 27-45.

Ryder, Andrew, T. Acton, S. Alexander, P. Cemelyn, S, Van Cleemput, J. Richardson, and D. Smith. 2011b. A Big or Divided Society? Final Recommendations and Report of the Panel Review into the Coalition Policy on Gypsies and Travellers. Travellers Aid Trust.

Sheridan, Richard. 2011. Interview at the Council of Europe. Podcast. December 8. Strasbourg. ww.humanrightseurope.org/2011/12/podcast-dale-farm-residents-to-challenge-eviction-at-humanrights-court.

Strathern, Marilyn. 1999. Property, Substance, and Effect: Anthropological essays on persons and things. London; New Brunswick NJ: Athlone Press.

Moser, Walter. 2002. The Acculturation of Waste. In Waste-Site Stories: The Recycling of Memory, ed. B. Neville and J. Villeneuve, 87-102 . New York: State University of New York Press.

Wickstrom, Maurya. 2012. Performance in the Blockades of Neoliberalism: thinking the political anew. New York, NY: Palgrave Macmillan. 